\title{
Validação do índice de comprometimento cutaneomucoso do pênfigo vulgar para a avaliação clínica de pacientes com pênfigo vulgar *
}

\author{
Validation of the Commitment Index of Skin and Mucous Membranes in \\ Pemphigus Vulgaris for the clinical evaluation of patients with pemphigus vulgaris
}

Sávio Reder de Souza ${ }^{1}$

Luna Azulay-Abulafia ${ }^{2}$

Leninha Valério do Nascimento ${ }^{3}$

\begin{abstract}
BaCKGRound: Pemphigus vulgaris is a severe bullous disease, produced by the autoimmune destruction of desmosomes, resulting in the formation of intraepidermal blisters, affecting skin and mucous membranes, with a mortality of 5 to $10 \%$. Side effects of therapy contributed to increased morbidity, accounting for considerable part of the immediate causes of death due to PV today. There is no reproducible score for clinical evaluation of patients with Pemphigus vulgaris, making the therapeutic decision subjective, and its results, uncertain. ОвJестіvEs: Create and evaluate the reproducibility of a scoring system for clinical evaluation of patients with pemphigus vulgaris.

METHODS: The Commitment Index of Skin and Mucous in Pemphigus Vulgaris was created, scoring easily observed findings on clinical examination. During 3 years, 7 patients with active PV were submitted to pairings of Commitment Index of Skin and Mucous in Pemphigus Vulgaris conduced by independent examiners for determinate its reproducibility.

RESUlTs: The Commitment Index of Skin and Mucous in Pemphigus Vulgaris proved that it is reproducible in all the statistical methods used to assess agreement between the independent examiners. In adition, it permited us to separate the patients into classes of severity.

Conclusion: The Commitment Index of Skin and Mucous in Pemphigus Vulgaris can classify the severity of Pemphigus Vulgaris, contributing to medical research, and to the standardization of the therapy in the near future.
\end{abstract}

Keywords: Pemphigus, Severity of Illness Index, Therapeutics

Resumo: FunDAMENTOS: O pênfigo vulgar é uma bulose grave, produzida pela destruição autoimune dos desmossomos, o que resulta na formação de bolhas intraepidérmicas, afetando pele e mucosas, com mortalidade de 5 a $10 \%$. Os efeitos colaterais da terapêutica contribuíram para aumentar a morbidade da doença, respondendo por parte considerável das causas imediatas de morte por pênfigo vulgar atualmente. Não há nenhuma sistematização reprodutível para a avaliação clínica dos pacientes de pênfigo vulgar, tornando a decisão terapêutica subjetiva e os seus resultados, incertos.

OвJетіvo: Validar um escore para a avaliação clínica dos pacientes com pênfigo vulgar.

MÉTODO: O índice de comprometimento cutaneomucoso do pênfigo vulgar foi criado, pontuando achados de fácil observação no exame clínico. Durante três anos, sete pacientes com pênfigo vulgar foram acompanhados e submetidos, em cada consulta, a pareamentos independentes do índice de comprometimento cutaneomucoso do pênfigo vulgar com vistas à aferição da sua reprodutibilidade.

RESULTADOS: O índice de comprometimento cutaneomucoso do pênfigo vulgar se mostrou reprodutível em todos os métodos estatísticos utilizados para avaliação da concordância entre os examinadores independentes, permitindo, ainda, separar os pacientes em classes de gravidade crescente.

CONCLUSÃo: O índice de comprometimento cutaneomucoso do pênfigo vulgar pode ajudar na classificação da gravidade do pênfigo vulgar, contribuindo para a pesquisa médica e para a uniformização das condutas terapêuticas num futuro próximo.

Palavras-chave: Índice de gravidade de doença; Pênfigo; Terapêutica

Received on 26.11.2009.

Approved by the Advisory Board and accepted for publication on 20.06.10

* Study conducted at the Pedro Ernesto Teaching Hospital, State University of Rio de Janeiro, Rio de Janeiro, Brazil.

Conflict of interest: None / Conflito de interesse: Nenhum

Financial funding: None / Suporte financeiro: Nenbum

Master's degree awarded by the State University of Rio de Janeiro (UERJ). Coordinator of Medical Research, Central Hospital for the Armed Forces (HCE), Rio de Janeiro, Brazil. Doctorate student in the Postgraduate Program in Clinical and Experimental Physiopathology (FISCLINEX), School of Medical Sciences, State University of Rio de Janeiro (UERJ).

Doctorate in dermatology awarded by the Federal University of Rio de Janeiro (UFRJ). Adjunct Professor of the Department of Dermatology, State University of Rio de Janeiro (UERJ), Rio de Janeiro, Brazil.

Post-doctorate in dermatology at the University of Paris. Coordinator of the Lato Senso Postgraduate Program in Dermatology of the University of Grande Rio (UNIGRANRIO) at the Central Hospital for the Armed Forces (HCE), Rio de Janeiro, Brazil.

(C)2011 by Anais Brasileiros de Dermatologia 


\section{INTRODUCTION}

The term "pemphigus" comes from the Greek "pemphix" meaning "blister" and refers to the principal clinical finding in this disease. ${ }^{1,2}$ The term was first used by Sauvages in 1760 and again by Wichman in $1791 .^{3}$ It refers to a group of rare autoimmune diseases in which blisters develop on the skin surface.

There are three principal variants of pemphigus: pemphigus vulgaris, pemphigus foliaceus and paraneoplastic pemphigus ${ }^{4}$, all of which involve the development of intradermal blisters ${ }^{5}$ secondary to an immunological attack on epithelial cell adhesion molecules. ${ }^{6}$ Various studies have shown that the circulating antibodies associated with the skin in cases of pemphigus belong predominantly to different IgG classes, particularly IgG1 and IgG4.

Of the three variants of pemphigus, the most severe is paraneoplastic pemphigus in view of its association with known or occult malignancy. Mortality is over $90 \%$ with this form of pemphigus even when aggressive treatment is implemented. ${ }^{5}$ Mortality is lower with pemphigus foliaceus; however, pemphigus vulgaris, the most common of the three types of pemphigus, was invariably fatal as a consequence of infections until the mid-twentieth century when the introduction of immunosuppressive corticotherapy dramatically reduced the mortality rates of this disease. ${ }^{5}$

Despite being the most common type of pemphigus, the incidence of pemphigus vulgaris, which is the subject of this paper, is low, around $0.1-0.5$ new cases per 100,000 inhabitants per year ${ }^{2-4}$. This does not, however, diminish the importance of this disease, since treatment for the condition has transformed it into a chronic rather than a fatal disease, thus contributing towards increasing its prevalence. Furthermore, despite its relative rarity, the impact of pemphigus vulgaris on affected patients is devastating. Camacho-Alonso et al. ${ }^{8}$ reported that pemphigus vulgaris affects individuals of both sexes, principally those in the 30-60 year age-group; however, cases have also been described in children and adolescents.

Despite the different immunosuppressive drugs currently available, pemphigus vulgaris-associated mortality may reach as high as $10 \%$ of all cases, a considerable proportion of which result from complications related to the treatment itself. ${ }^{4}$ Therefore, knowledge on how to correctly evaluate the extent and severity of pemphigus vulgaris in each individual case is fundamental to the success or failure of treatment.

Unfortunately, there are no well-defined clinical parameters that permit patients with pemphigus vulgaris to be adequately classified ${ }^{9}$, making clinical evaluation and, consequently, decisions regarding treatment, highly dependent on the experience of the professional examining the patient, which does not always result in the best outcome. The objective of the present study was to create a reproducible clinical score that would contribute towards standardizing the clinical evaluation of patients with pemphigus vulgaris and to suggest an ordinal classification system (in categories of increasing severity, based on the Index of Skin and Mucous Involvement in Pemphigus Vulgaris (ISMIPV) used to assess patients with pemphigus vulgaris.

\section{MATERIAL AND METHODS \\ Creation of the clinical score}

Application of the ISMIPV results in a total score that is based on the evaluation of four different items (Table 1):

The number of blisters or erosions where a blister had previously been present (i.e. includes blisters that have already ruptured). Areas of residual post-inflammatory pigmentation should be excluded. Score: $0-25$ points.

Size of the blisters or erosions. Only the largest visible lesion should be taken into consideration, the greatest diameter of which should be measured and included in the score. If the patient has more than $20 \%$ of his/her body area covered with whole or ruptured blisters, this is also reflected in the score. Score: $0-25$ points.

Nikolsky's sign. This item receives a score if Nikolsky's sign or the Asboe-Hansen sign is positive, both being indicative of the active disease. Score: 0 or 20 points.

Involvement of mucous membranes and sepsis. For the purpose of scoring, the following sites are considered mucous membranes: eyes, nose, ears, mouth, anus and external genitalia. The number of lesions at each one of these sites is not important, i.e. if the site is affected at all, this counts as one mucous membrane site when adding the score. In this item and for the purpose of calculating the score, only intense and/or persistent restrictions to the affected mucous membrane site are considered to represent severe functional repercussions. Examples: conjunctival synechiae; the patient's inability to feed him/herself and a weight loss $>10 \%$ since the mucous membrane site was first affected; stenoses of natural orifices; mucous membrane infections with sepsis. Patients with sepsis due to skin lesions also receive a maximum score in this item even if they have no visible mucous membrane involvement. Score: $0-30$ points.

Total ISMIPV score is the result of the sum of the scores awarded in the four items outlined above and may range from 0 to 100 points, grouped into 5- 
TABLE 1: Index of Skin and Mucous Involvement in Pemphigus Vulgaris (ISMIPV)

\begin{tabular}{|c|c|c|c|}
\hline Item & Points & Description & Score \\
\hline $\begin{array}{l}\text { Number of blisters or ulcerated or } \\
\text { encrusted areas where blisters had } \\
\text { previously been. }\end{array}$ & $\begin{array}{l}0 \\
5 \\
10 \\
15 \\
20 \\
25\end{array}$ & $\begin{array}{l}\text { No blisters } \\
1-5 \text { blisters } \\
6-10 \text { blisters } \\
11-15 \text { blisters } \\
16-20 \text { blisters } \\
>20 \text { blisters }\end{array}$ & \\
\hline $\begin{array}{l}+ \\
\text { Size of the blisters or ulcerated or } \\
\text { encrusted areas where blisters had } \\
\text { previously been. }\end{array}$ & $\begin{array}{l}0 \\
5 \\
10 \\
15 \\
20 \\
25\end{array}$ & $\begin{array}{l}\text { No blisters } \\
\text { Largest lesion } \leq 50 \mathrm{~mm} \text { in diameter } \\
50.1-7.5 \mathrm{~cm} \\
7.6-10 \mathrm{~cm} \\
>10 \mathrm{~cm} \\
\text { Lesions covering }>20 \% \text { of the body surface }\end{array}$ & \\
\hline $\begin{array}{l}+ \\
\text { Nikolsky's sign and/or the } \\
\text { Asboe-Hansen sign }\end{array}$ & $\begin{array}{l}0 \\
20\end{array}$ & $\begin{array}{l}\text { No signs } \\
\text { One or both signs present }\end{array}$ & \\
\hline $\begin{array}{l}+ \\
\text { Mucous membrane involvement } \\
\text { and/or sepsis }\end{array}$ & $\begin{array}{l}0 \\
10 \\
20 \\
30\end{array}$ & $\begin{array}{l}\text { No mucous membrane lesions } \\
1 \text { mucous membrane site } \\
2 \text { mucous membrane sites } \\
\geq 3 \text { mucous membrane sites, or severe } \\
\text { functional repercussion of mucous membrane } \\
\text { involvement (irrespective of the number of } \\
\text { sites) or sepsis (with or without mucous } \\
\text { membrane involvement) }\end{array}$ & \\
\hline Total: & \multicolumn{2}{|c|}{ Sum of all the items } & $0-100$ \\
\hline
\end{tabular}

point intervals (possible ISMIPV scores: $0,5,10,15$, $20,25,30,35,40,45,50,55,60,65,70,75,80,85$, 90, 95 and 100, i.e. there are 21 possible scores).

As shown, the ISMIPV can be classified as a discrete quantitative variable, since infinite values, unlike continuous variables, are impossible within a defined range of scores. The likelihood of chance agreement in paired scores is also visible and would be equal to the product of $1 / 21$ multiplied by $1 / 21$ - an overall likelihood of 1 in 441 or approximately $0.227 \%$.

\section{Definition of the experimental design and sam- ple size}

To validate the ISMIPV, a clinical trial was conducted in which patients with pemphigus vulgaris were followed up and submitted at each return visit to clinical examination by two independent examiners (each blinded to the other's evaluation) to calculate the ISMIPV score. The two ISMIPV scores obtained from the two evaluators were referred to as "pairs".

Sample size (the number of pairs necessary to validate the ISMIPV) was calculated at 75 pairs. This calculation was performed using the Epidat software program, version 3.1. From the initial page of the program, the following sequence was then selected: methods $>$ sample $>$ calculation of sample size $>$ agreement. The data inserted in the calculation spreadsheet consisted of the expected kappa coefficient of 0.81 ; the proportion of positive classifications from both examiners, which was defined at $85 \%$; a 95\% confidence interval; a minimum absolute precision of 0.001 and maximum absolute precision of 0.19 . The sample size that resulted from this calculation was therefore selected.

\section{Patient selection}

The study protocol was submitted to the Internal Review Board of the Pedro Ernesto Teaching Hospital, State University of Rio de Janeiro (UERJ) and ethical approval was obtained prior to initiation of the patient selection procedure. Adult patients with pemphigus vulgaris, both men and women, were selected for the study whether they had received previous treatment for the disease or not, in accordance with 
the availability of patients at the institute's dermatology clinic.

Patients who did not volunteer for participation in the study were not included nor were those who stated at the selection interview that there were social difficulties or some other form of impediment preventing them from attending the clinic regularly for follow-up.

All patients who participated in the study signed the informed consent form.

\section{Clinical follow-up of patients}

The patients selected for inclusion in the study were followed up at the dermatology clinic at intervals that ranged from weekly to monthly.

At each paired examination, performed as described above, the principal investigator of the study was always the first examiner. The second examiner was not always the same dermatologist, since various professionals contributed to the study as the second examiner by evaluating these patients and calculating their scores. It was not possible to achieve pairings at all consultations because on several occasions a second examiner was not available.

Evaluation of the activity of the disease was based exclusively on the clinical evaluation performed in accordance with the ISMIPV, not only because this was the objective of the study but also because there were no other means available for following up the activity of this disease, such as indirect immunofluorescence or measurement of serum auto-antibodies.

All the patients selected for inclusion in the study received the treatment they required, either topic or systemic, during their follow-up.

\section{Results}

Seven patients with pemphigus vulgaris were selected and followed up at the dermatology clinic of this university teaching hospital between the first half of 2006 and the second half of 2008. This follow-up resulted in 76 ISMIPV pairings.

Tables 2, 3 and 4 show the usefulness of the ISMIPV in describing samples, since the results obtained from the two observers were very similar, as shown in the analysis of the 76 ISMIPV scores obtained from examiner \#1 and compared with the scores obtained from the second examiner in each case.

Figure 1 shows a strong positive correlation between the paired ISMIPV scores, which was quantified by Pearson's correlation ( $r$ ), calculated as $>0.8$.

As shown in Figure 1, Pearson's correlation (r) of the paired ISMIPV scores was $0.92838250[95 \%$ confidence interval (95\%CI): 0.888 - 0.954; $\mathrm{p}<0.0001]$.

TABLE 2: Frequency of the ISMIPV values obtained by Examiner \#1

\begin{tabular}{llll}
\hline Score & Frequency & $\%$ & Accumulated \% \\
\hline 0 & 7 & $9.2 \%$ & $9.2 \%$ \\
10 & 13 & $17.1 \%$ & $26.3 \%$ \\
15 & 1 & $1.3 \%$ & $27.6 \%$ \\
20 & 19 & $25.0 \%$ & $52.6 \%$ \\
25 & 3 & $3.9 \%$ & $56.6 \%$ \\
30 & 4 & $5.3 \%$ & $61.8 \%$ \\
40 & 5 & $6.6 \%$ & $68.4 \%$ \\
50 & 6 & $7.9 \%$ & $76.3 \%$ \\
55 & 1 & $1.3 \%$ & $77.6 \%$ \\
60 & 4 & $5.3 \%$ & $82.9 \%$ \\
65 & 2 & $2.6 \%$ & $85.5 \%$ \\
70 & 1 & $1.3 \%$ & $86.8 \%$ \\
75 & 7 & $9.2 \%$ & $96.1 \%$ \\
85 & 3 & $3.9 \%$ & $100.0 \%$ \\
Total & 76 & $100.0 \%$ & $100.0 \%$ \\
& & & \\
\hline
\end{tabular}

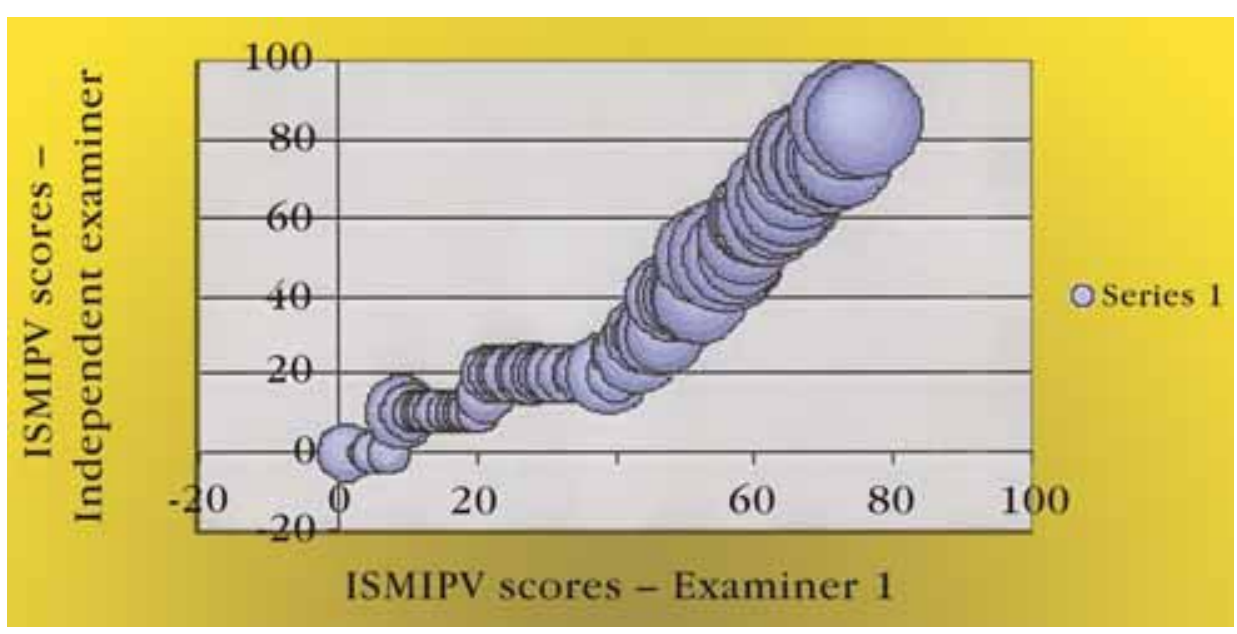

Figure 1: The Pearson correlation (r) between the values of Examiner \#1 and those of Examiner \#2 was 0.928382501 , considering that, if $0.8=r<1$, it is understood that the correlation between the two variables is strongly positive, i.e. if the ISMIPV score obtained by Examiner \# 1 increases, the same is true for the score of Examiner \#2 
TABLE 3: Frequency of the ISMIPV values obtained by Examiner \#2

\begin{tabular}{llll}
\hline Score & Frequency & $\%$ & Accumulated \% \\
\hline 0 & 5 & $6.6 \%$ & $6.6 \%$ \\
5 & 1 & $1.3 \%$ & $7.9 \%$ \\
10 & 16 & $21.1 \%$ & $28.9 \%$ \\
20 & 13 & $17.1 \%$ & $46.1 \%$ \\
25 & 5 & $6.6 \%$ & $52.6 \%$ \\
30 & 2 & $2.6 \%$ & $55.3 \%$ \\
35 & 3 & $3.9 \%$ & $59.2 \%$ \\
40 & 9 & $11.8 \%$ & $71.1 \%$ \\
45 & 1 & $1.3 \%$ & $72.4 \%$ \\
50 & 3 & $3.9 \%$ & $76.3 \%$ \\
55 & 3 & $3.9 \%$ & $80.3 \%$ \\
60 & 5 & $6.6 \%$ & $86.8 \%$ \\
65 & 3 & $3.9 \%$ & $90.8 \%$ \\
70 & 2 & $2.6 \%$ & $93.4 \%$ \\
75 & 4 & $5.3 \%$ & $98.7 \%$ \\
85 & 1 & $1.3 \%$ & $100.0 \%$ \\
Total & 76 & $100.0 \%$ & $100.0 \%$ \\
\hline
\end{tabular}

\section{Analysis of variance (ANOVA)}

Analysis of variance (ANOVA) enables the hypothesis to be tested that there is no statistically significant difference between the paired ISMIPV scores at different significance levels, as shown in Table 5.

Using analysis of variance, as shown above, no statistically significant differences were found between the paired ISMIPV scores, which increased the reproducibility of the score.

\section{T-test applied to the paired values (paired t-test)}

Let us imagine another hypothesis: that the differences found between the ISMIPV scores are not statistically significant. By applying the t-test, it is possible to accept or reject this hypothesis, which we will refer to as $\mathrm{H}_{0}$ (null hypothesis), as shown in Table 6.

As shown by the $\mathrm{t}$-test, there were no statistically significant differences in the paired ISMIPV scores, a result that places further emphasis on the repro- ducibility of the ISMIPV score. Nevertheless, the degree of agreement between the two examiners has still to be measured directly. To do so, the kappa coefficient was calculated.

\section{Kappa coefficient}

Table 7 shows the degree of correspondence between the two examiners with respect to the ISMIPV scores of the 76 pairings. The EDIDAT software program, version 3.1, was used to calculate the kappa coefficient, which describes the degree of agreement between the different observers and, consequently, the reproducibility of this score for the $\mathbf{7 6}$ pairs of evaluations. The kappa coefficient for the ISMIPV was 0.3492 (95\%CI: 0.2341 to 0.4642 ; $\mathrm{p}<0.0001)$. The variation in the kappa coefficient obtained in this study reveals that inter-examiner agreement was, at first sight, average to moderate (Table 8). Nevertheless, the following should be taken into consideration: of the 76 pairs, the two examiners obtained the same ISMIPV score 32 times (as shown by the diagonal line in Table 7). With respect to the other pairs, the difference between ISMIPV scores was slight. This distinction between a small and a large difference, however, was not taken into consideration in calculating the kappa coefficient. It is possible to do this by using the EPIDAT 3.1 to calculate the weighted kappa coefficient, helping it reflect not only the proportion of perfect agreement but also the frequency with which the agreement, although not perfect, was very similar. To do so, quadratic weights and Cicchetti weights, two of the most commonly used methods for calculating weighted kappa coefficients, were used.

\section{Kappa coefficient weighted using Cicchetti weights}

The abovementioned calculations were repeated using the same data, with the kappa weighted by Cicchetti weights. A weighted kappa coefficient of 0.7692 was found $(95 \% \mathrm{CI}: 0.7104$ to 0.8274 ; $\mathrm{p}<0.0001)$. These results permitted the inter-observer agreement for the ISMIPV to be classified as good to excellent within the $95 \%$ confidence interval.

TABLE 4: Comparison between the statistical parameters of the ISMIPV values obtained by the independent examiners

\begin{tabular}{llll}
\hline \multicolumn{1}{c}{ ISMIPV - Examiner \#1 } & \multicolumn{1}{c}{ ISMIPV - Examiner \#2 } \\
\hline Mean & 32.82894737 & Mean & 32,30263158 \\
Median & 20 & Median & 25 \\
Mode & 20 & Mode & 10 \\
Variance & 633,5570175 & Variance & 524,2938596 \\
Standard deviation & 25,17055855 & Standard deviation & 22,8974604 \\
\hline
\end{tabular}


TABLE 5: Analysis of Variance (ANOVA)

\begin{tabular}{llll}
\hline & $\begin{array}{l}\text { F-value } \\
\text { obtained }\end{array}$ & $\begin{array}{l}\text { Table } \\
\text { F-value }\end{array}$ & Interpretation \\
\hline $\begin{array}{l}\text { For a significance } \\
\text { level of 1\% }\end{array}$ & 0.018183 & 6.806894 & $\begin{array}{l}\text { Table F }>\text { F-value obtained. It is understood that the ISMIPV } \\
\text { values of Examiner \# } 1 \text { and those of Examiner \#2 are not } \\
\text { different at a } 1 \% \text { significance level. }\end{array}$ \\
For a significance & level of 5\% & 0.018183 & $\begin{array}{l}\text { 3.904202 Table F > F-value obtained. It is understood that } \\
\text { the ISMIPV values of Examiner \#1 and those of Examiner \#2 } \\
\text { are not different at a 5\% significance level. }\end{array}$ \\
For a significance & level of 10\% & 0.018183 & $\begin{array}{l}2.739275 \text { Table F }>\text { F-value obtained. It is understood that } \\
\text { the ISMIPV values of Examiner \#1 and those of Examiner \#2 } \\
\text { are not different at a 10\% significance level. }\end{array}$ \\
\hline
\end{tabular}

\section{Kappa coefficient weighted using quadratic weights}

The abovementioned calculations were then repeated using the same data, with the kappa weighted by quadratic weights. A weighted kappa coefficient of 0.9240 was found (95\%CI: 0.8920 to 0.9561 ; $\mathrm{p}<0.0001)$. These results permitted the inter-observer agreement with respect to the ISMIPV to be classified as excellent, within the $95 \%$ confidence interval.

\section{Degrees of severity of pemphigus vulgaris}

Now consider the following situation: although the ISMIPV score is reproducible, as shown above, it is impossible to individualize therapy for each ISMIPV score. How, then, could the ISMIPV be used to group together patients with similar degrees of severity with the objective of helping the professional define the most appropriate form of treatment? The following classification is therefore proposed:
Class I: ISMIPV scores of 5-30

Class II: ISMIPV scores of 35-65

Class III: ISMIPV scores of $70-100$

The previously mentioned table of agreement was recalculated in accordance with this classification and is shown as Table 9.

The unweighted kappa coefficient obtained for the three classes was 0.6950 (95\%CI: 0.5579 to $0.8320 ; \mathrm{p}<0.0001)$, showing moderate to excellent agreement between the observers. However, calculation of the weighted kappa coefficient was as follows:

Using the Cicchetti weights: weighted kappa coefficient of 0.7548 (95\%CI: 06430 to 0.8667 ; $\mathrm{p}<0.0001$ ), indicating good to excellent inter-observer agreement, within the $95 \%$ confidence interval.

Using the quadratic weight: weighted kappa coefficient of 0.8239 (95\%CI: 0.7390 to 0.9089 ;

TABLe 6: T-test for Paired Samples

\begin{tabular}{|c|c|}
\hline Sum of the differences (Examiner \#2 minus Examiner \#1) & -40 \\
\hline Mean of the differences (Examiner \#2 minus Examiner \#1) & $-0,52632$ \\
\hline Median of the differences (Examiner \#2 minus Examiner \#1) & 0 \\
\hline Mode of the differences (Examiner \#2 minus Examiner \#1) & 0 \\
\hline $\begin{array}{l}\text { Standard deviation of the differences (Examiner \#2 } \\
\text { minus Examiner \#1) }\end{array}$ & 9,365858 \\
\hline $\begin{array}{l}\text { T calculado (teste t para amostras pareadas, com hipótese } \\
\text { nula significando não haver diferença entre os examinadores } \\
\text { nos pareamentos obtidos) }\end{array}$ & $\begin{array}{l}\text { - } 0.49 \text { (= calculated t-value) } \\
\text { - For significance level of } 1 \% \text { - calculated t-value - the } \\
\text { null hypothesis is accepted. } \\
\text { - For significance level of } 5 \% \text { - calculated t-value - the } \\
\text { null hypothesis is accepted } \\
\text { - For significance level of } 10 \% \text { - calculated t-value - the } \\
\text { null hypothesis is accepted. }\end{array}$ \\
\hline
\end{tabular}


$\mathrm{p}<0.0001$ ), indicating good to excellent inter-observer agreement within the $95 \%$ confidence interval.

\section{DISCUSSION}

With the exception of corticotherapy, which has been well established over more than 50 years of use, the therapeutic management of pemphigus vulgaris remains tenuous as far as evidence-based medicine is concerned. The majority of treatment modalities are based on series of cases or case reports or on the opinion of specialists. Statistical treatment of data is absent from the majority of papers, contributing towards the poor quality of the information provided.

To this day, no clinical score has been proposed that would be both reliable and easily accessible at all healthcare centers, and that could be used to standardize the clinical evaluation of patients with pemphigus vulgaris and objectively quantify the results of treatment implemented.

It is known, for example, that there is a correlation between the clinical activity of pemphigus vulgaris and serum levels of anti-desmoglein 1 and 3 antibodies ${ }^{10}$, with a strong correlation between antidesmoglein 3 antibody levels measured by ELISA and the findings of indirect immunofluorescence in pem- phigus vulgaris. ${ }^{11}$ Nevertheless, these tests are expensive and are not within the reach of the majority of patients and institutions, particularly those in the developing world.

\section{CONCLUSION}

This study confirms that use of the ISMIPV results in a clinical score that is reproducible and simple both to understand and to implement. Interexaminer agreement was maintained both when the score was used as a quantitative variable (as an absolute value - a discrete quantitative variable) and when it was used qualitatively (considering the degrees of severity of the ISMIPV - a qualitative ordinal variable).

Use of the ISMIPV to assess the clinical status of the patient with pemphigus vulgaris translates the recording of observations into numbers and provides better conditions both for conducting retrospective case-control studies and prospective studies (either observational or intervention studies) by improving the statistical treatment of data.

The classification of patients with pemphigus vulgaris into increasing degrees of severity in accordance with their ISMIPV score may facilitate the stan-

TABLE 7: Correspondence between the ISMIPV values of the independent examiners

EXAMINER \#2

\begin{tabular}{|c|c|c|c|c|c|c|c|c|c|c|c|c|c|c|c|c|c|c|c|c|c|c|c|}
\hline \multicolumn{2}{|c|}{ ISMIPV } & \multirow{2}{*}{$\begin{array}{l}0 \\
3\end{array}$} & \multirow{2}{*}{$\begin{array}{l}5 \\
1\end{array}$} & \multirow{2}{*}{$\begin{array}{l}10 \\
2\end{array}$} & \multirow{2}{*}{$\begin{array}{l}15 \\
0\end{array}$} & \multirow{2}{*}{$\begin{array}{c}20 \\
1\end{array}$} & \multirow{2}{*}{$\begin{array}{c}25 \\
0\end{array}$} & \multirow{2}{*}{$\begin{array}{l}30 \\
0\end{array}$} & \multirow{2}{*}{$\begin{array}{l}35 \\
0\end{array}$} & \multirow{2}{*}{$\begin{array}{c}40 \\
0\end{array}$} & \multirow{2}{*}{$\begin{array}{c}45 \\
0\end{array}$} & \multirow{2}{*}{$\begin{array}{l}50 \\
0\end{array}$} & & \multirow{2}{*}{$\begin{array}{c}60 \\
0\end{array}$} & \multirow{2}{*}{$\begin{array}{l}65 \\
0\end{array}$} & \multirow{2}{*}{$\begin{array}{l}70 \\
0\end{array}$} & \multirow{2}{*}{$\begin{array}{l}75 \\
0\end{array}$} & \multirow{2}{*}{$\begin{array}{l}80 \\
0\end{array}$} & \multirow{2}{*}{$\begin{array}{l}85 \\
0\end{array}$} & \multirow{2}{*}{$\begin{array}{c}90 \\
0\end{array}$} & \multirow{2}{*}{$\begin{array}{l}95 \\
0\end{array}$} & \multirow{2}{*}{$\begin{array}{l}100 \\
0\end{array}$} & \multirow{2}{*}{$\begin{array}{l}\text { Total } \\
7\end{array}$} \\
\hline $\mathbf{E}$ & 0 & & & & & & & & & & & & & & & & & & & & & & \\
\hline $\mathbf{X}$ & 5 & 0 & 0 & 0 & 0 & 0 & 0 & 0 & 0 & 0 & 0 & 0 & 0 & 0 & 0 & 0 & 0 & 0 & 0 & 0 & 0 & 0 & 0 \\
\hline $\mathbf{A}$ & 10 & 1 & 0 & 10 & 0 & 1 & 0 & 1 & 0 & 0 & 0 & 0 & 0 & 0 & 0 & 0 & 0 & 0 & 0 & 0 & 0 & 0 & 13 \\
\hline M & 15 & 0 & 0 & 0 & 0 & 1 & 0 & 0 & 0 & 0 & 0 & 0 & 0 & 0 & 0 & 0 & 0 & 0 & 0 & 0 & 0 & 0 & 1 \\
\hline I & 20 & 1 & 0 & 4 & 0 & 10 & 3 & 0 & 0 & 1 & 0 & 0 & 0 & 0 & 0 & 0 & 0 & 0 & 0 & 0 & 0 & 0 & 19 \\
\hline $\mathbf{N}$ & 25 & 0 & 0 & 0 & 0 & 0 & 2 & 0 & 0 & 1 & 0 & 0 & 0 & 0 & 0 & 0 & 0 & 0 & 0 & 0 & 0 & 0 & 3 \\
\hline $\mathbf{E}$ & 30 & 0 & 0 & 0 & 0 & 0 & 0 & 1 & 2 & 1 & 0 & 0 & 0 & 0 & 0 & 0 & 0 & 0 & 0 & 0 & 0 & 0 & 4 \\
\hline \multirow{2}{*}{$\mathbf{R}$} & 35 & 0 & 0 & 0 & 0 & 0 & 0 & 0 & 0 & 0 & 0 & 0 & 0 & 0 & 0 & 0 & 0 & 0 & 0 & 0 & 0 & 0 & 0 \\
\hline & 40 & 0 & 0 & 0 & 0 & 0 & 0 & 0 & 0 & 3 & 1 & 1 & 0 & 0 & 0 & 0 & 0 & 0 & 0 & 0 & 0 & 0 & 5 \\
\hline \# & 45 & 0 & 0 & 0 & 0 & 0 & 0 & 0 & 0 & 0 & 0 & 0 & 0 & 0 & 0 & 0 & 0 & 0 & 0 & 0 & 0 & 0 & 0 \\
\hline \multirow[t]{11}{*}{1} & 50 & 0 & 0 & 0 & 0 & 0 & 0 & 0 & 1 & 2 & 0 & 0 & 1 & 1 & 0 & 0 & 1 & 0 & 0 & 0 & 0 & 0 & 6 \\
\hline & 55 & 0 & 0 & 0 & 0 & 0 & 0 & 0 & 0 & 0 & 0 & 1 & 0 & 0 & 0 & 0 & 0 & 0 & 0 & 0 & 0 & 0 & 1 \\
\hline & 60 & 0 & 0 & 0 & 0 & 0 & 0 & 0 & 0 & 1 & 0 & 1 & 1 & 1 & 0 & 0 & 0 & 0 & 0 & 0 & 0 & 0 & 4 \\
\hline & 65 & 0 & 0 & 0 & 0 & 0 & 0 & 0 & 0 & 0 & 0 & 0 & 0 & 1 & 0 & 0 & 1 & 0 & 0 & 0 & 0 & 0 & 2 \\
\hline & 70 & 0 & 0 & 0 & 0 & 0 & 0 & 0 & 0 & 0 & 0 & 0 & 0 & 0 & 1 & 0 & 0 & 0 & 0 & 0 & 0 & 0 & 1 \\
\hline & 75 & 0 & 0 & 0 & 0 & 0 & 0 & 0 & 0 & 0 & 0 & 0 & 0 & 2 & 2 & 2 & 1 & 0 & 0 & 0 & 0 & 0 & 7 \\
\hline & 80 & 0 & 0 & 0 & 0 & 0 & 0 & 0 & 0 & 0 & 0 & 0 & 0 & 0 & 0 & 0 & 0 & 0 & 0 & 0 & 0 & 0 & 0 \\
\hline & 85 & 0 & 0 & 0 & 0 & 0 & 0 & 0 & 0 & 0 & 0 & 0 & 1 & 0 & 0 & 0 & 1 & 0 & 1 & 0 & 0 & 0 & 3 \\
\hline & 90 & 0 & 0 & 0 & 0 & 0 & 0 & 0 & 0 & 0 & 0 & 0 & 0 & 0 & 0 & 0 & 0 & 0 & 0 & 0 & 0 & 0 & 0 \\
\hline & 95 & 0 & 0 & 0 & 0 & 0 & 0 & 0 & 0 & 0 & 0 & 0 & 0 & 0 & 0 & 0 & 0 & 0 & 0 & 0 & 0 & 0 & 0 \\
\hline & 100 & 0 & 0 & 0 & 0 & 0 & 0 & 0 & 0 & 0 & 0 & 0 & 0 & 0 & 0 & 0 & 0 & 0 & 0 & 0 & 0 & 0 & 0 \\
\hline \multicolumn{2}{|c|}{ Total } & 5 & 1 & 16 & 0 & 13 & 5 & 2 & 3 & 9 & 1 & 3 & 3 & 5 & 3 & 2 & 4 & 0 & 1 & 0 & 0 & 0 & 76 \\
\hline
\end{tabular}


TABLE 8: Interpretation of the agreement between the independent examiners according to the KAPPA coefficient

\begin{tabular}{ll}
\hline Kappa value & Agreement \\
\hline 0 & Absent \\
$>0-0.20$ & Slight \\
$0.21-0.40$ & Fair \\
$0.41-0.60$ & Moderate \\
$0.61-0.80$ & Good \\
$0.81-1.00$ & Excellent \\
\hline
\end{tabular}

dardization of treatment management by allowing a correlation to be made between the degree of severity of the patient and the successive lines of therapeutic action.

Finally, the degrees of severity defined accord-
TABLE 9: Degrees of severity in pemphigus vulgaris according to ISMIPV score

\begin{tabular}{|c|c|c|c|c|c|}
\hline \multirow{2}{*}{ \# } & \multirow[b]{2}{*}{ Classes } & \multicolumn{4}{|c|}{ Examiner \#2 } \\
\hline & & I & II & III & Total \\
\hline \multirow{4}{*}{ 离 } & I & 42 & 5 & 0 & 47 \\
\hline & II & 0 & 16 & 2 & 18 \\
\hline & III & 0 & 6 & 5 & 11 \\
\hline & Total & 42 & 27 & 7 & 76 \\
\hline
\end{tabular}

ing to the ISMIPV could be used to establish prognosis based on the initial presentation of pemphigus vulgaris; however, further prospective studies are required to investigate this possibility.

\section{REFERENCES}

1. Habif TP. Dermatologia clínica: guia colorido para diagnóstico e tratamento. 4 ed. São Paulo: Artmed; 2005. p. 561-600.

2. Scully $\mathrm{C}$, Challacombe S. Pemphigus vulgaris: update on etiopathogenesis, oral manifestations, and management. Crit Rev Oral Biol Med. 2002;13:397-408.

3. Sanchez-Pérez J, Garcia-Diez A. Pênfigo. Actas Dermosifiliogr. 2005;96:329-56.

4. Fellner MJ, Sapadin AN. Current therapy of pemphigus vulgaris. Mt Sinai J Med. 2001;68:268-78

5. Mimouni D, Anhalt GJ. Pemphigus. Dermatol Ther. 2002;15:362-8.

6. Aoki V, Yamazaki MH, Maruta CW, Lago F, Santi CG, The Cooperative Group on Fogo Selvagem Research. Significado do epitope spreading na patogênese dos pênfigos vulgar e foliáceo. An Bras Dermatol. 2008;83:157-61.

7. Sitaru C, Mihai S, Zillikens D. The relevance of the IgG subclass of autoantibodies for blister induction in autoimmune bullous skin diseases. Arch Dermatol. Res. 2007;299:1-8

8. Camacho-Alonso F, López-Jornet P, Bermejo-Fenoll A. Pemphigus vulgaris. A presentation of 14 cases and review of the literature. Med Oral Patol Oral Cir Bucal. 2005:10:282-8.

9. Pfutze M, Niedermeier A, Hertl M, Eming R. Introducing a novel Autoimmune Bullous Skin Disorder Intensity Score (ABSIS) in pemphigus. Eur J Dermatol. 2007;17:4-11.

10. Odom RB, James WD, Berger TG, eds. Andrew's Diseases of the Skin - Clinical Dermatology, 9th ed. USA: Saunders; 2000. p. 574-605.

11. Lenz P, Amagai M, Volc-Platzer B, Stingl G, Kirnbauer R. Desmoglein 3-ELISA: a pemphigus vulgaris -specific diagnostic tool. Arch Dermatol. 1999;135:143-8.

MAILING ADDRESS / ENDEREÇO PARA CORRESPONDÊNCIA: Sávio Reder de Souza

Rua Miguel de Frias, 41, ap. 801, bloco 3, Icaraí

24220-008 Niterói, RJ, Brazil

E-mail: physician-d@uol.com.br

How to cite this article/Como citar este artigo: Souza SR, Azulay-Abulafia L, Nascimento LV. Validation of an index of skin and mucous involvement for the clinical evaluation of patients with Pemphigus Vulgaris. An Bras Dermatol. 2011;86(2):284-91. 